\title{
U.S. International Transactions in 2001
}

William L. Helkie, of the Board's Division of International Finance, prepared this article. Sara B. Holland provided research assistance.

The U.S. current account deficit narrowed noticeably in 2001. Both imports and exports of goods and services fell during the year in response to a global weakening of economic activity. The decline in the deficit followed a substantial widening during most of the past decade. For 2001, a smaller merchandise trade deficit and a slightly larger surplus in trade in services offset a continued widening of the deficit on investment income.

Meager foreign economic growth and the continued real appreciation of the dollar throughout the year induced a $\$ 61$ billion decline in the value of U.S. exports of goods and services. The slowing in the U.S. economy caused imports of goods and services to fall even more $-\$ 89$ billion. In the third quarter the deficit declined further, but only temporarily, because payments for imported services were reduced by a one-time large estimated insurance payment from foreign insurers (reported on an accrual basis) related to the destruction caused by the terrorist attacks of September 11. The net effect of these developments was a $\$ 28$ billion narrowing in the goods and services deficit for 2001 (table 1).

The deficit in investment income widened slightly. Higher net payments on the growing net portfolio liability position were nearly offset by higher net receipts from direct investment. Weak growth abroad and the effect of lower oil prices on the profitability of U.S. energy companies lowered the return on U.S. foreign direct investment assets; slower growth in the United States reduced the return on foreign direct investment assets in the United States by an even greater amount. The deficit on unilateral transfers narrowed slightly.

Although smaller than the deficit in 2000, the U.S. current account deficit in 2001 was still large relative to U.S. historical experience (chart 1). The U.S. current account deficit is the counterpart of a net inflow of foreign capital that represents a source of saving (of more than $\$ 400$ billion) to help finance U.S. domestic investment. To finance the U.S. current account deficit, net private capital flowed in at a record pace in 2001 and included unprecedented net inflows through private securities transactions. Net official capital outflows were slight. The statistical discrepancy in the U.S. international accounts was

1. U.S, international transactions, 1997-2001

Billions of dollars except as noted

\begin{tabular}{|c|c|c|c|c|c|c|}
\hline Item & 1997 & 1998 & 1999 & 2000 & 2001 & $\begin{array}{l}\text { Change, } \\
2000-01\end{array}$ \\
\hline $\begin{array}{l}\text { Trade in goods and services, net } \\
\text { Goods } \\
\text { Services } \ldots \ldots \ldots \ldots \ldots \ldots \ldots \ldots\end{array}$ & $\begin{array}{r}-108 \\
-198 \\
90\end{array}$ & $\begin{array}{r}-167 \\
-247 \\
80\end{array}$ & $\begin{array}{r}-262 \\
-346 \\
83\end{array}$ & $\begin{array}{r}-376 \\
-452 \\
76\end{array}$ & $\begin{array}{r}-348 \\
-427 \\
79\end{array}$ & $\begin{array}{r}28 \\
25 \\
3\end{array}$ \\
\hline $\begin{array}{l}\text { Investment income, net } \ldots \ldots \ldots \\
\text { Compensation of employees, net } \\
\text { Unilateral current transfers, net .. }\end{array}$ & $\begin{array}{r}13 \\
-5 \\
-41\end{array}$ & $\begin{array}{r}-1 \\
-5 \\
-44\end{array}$ & $\begin{array}{r}-9 \\
-5 \\
-49\end{array}$ & $\begin{array}{r}-10 \\
-5 \\
-54\end{array}$ & $\begin{array}{r}-14 \\
-5 \\
-51\end{array}$ & $\begin{array}{r}-4 \\
0 \\
3\end{array}$ \\
\hline Current account balance ... & -140 & -217 & -324 & -445 & -417 & 28 \\
\hline $\begin{array}{l}\text { Official capital, net } \\
\text { Private capital, net } \ldots \ldots \ldots \ldots \ldots \ldots \ldots \ldots \ldots \ldots \ldots\end{array}$ & $\begin{array}{r}18 \\
254\end{array}$ & $\begin{array}{l}-27 \\
172\end{array}$ & $\begin{array}{r}55 \\
322\end{array}$ & $\begin{array}{r}36 \\
407\end{array}$ & $\begin{array}{r}1 \\
455\end{array}$ & $\begin{array}{r}-35 \\
48\end{array}$ \\
\hline Financial account balance & 272 & 145 & 377 & 443 & 456 & 13 \\
\hline Capital account balance & $\mathbf{0}$ & 1 & -3 & 1 & 1 & $\mathbf{0}$ \\
\hline Statistical discrepancy & -132 & 72 & -49 & 1 & -39 & -40 \\
\hline $\begin{array}{l}\text { Memo } \\
\text { Current account balance as percent of GDP .... }\end{array}$ & -1.7 & -2.5 & -3.5 & -4.5 & -4.1 & $4^{1}$ \\
\hline
\end{tabular}


1. U.S. external balances, 1970-2001

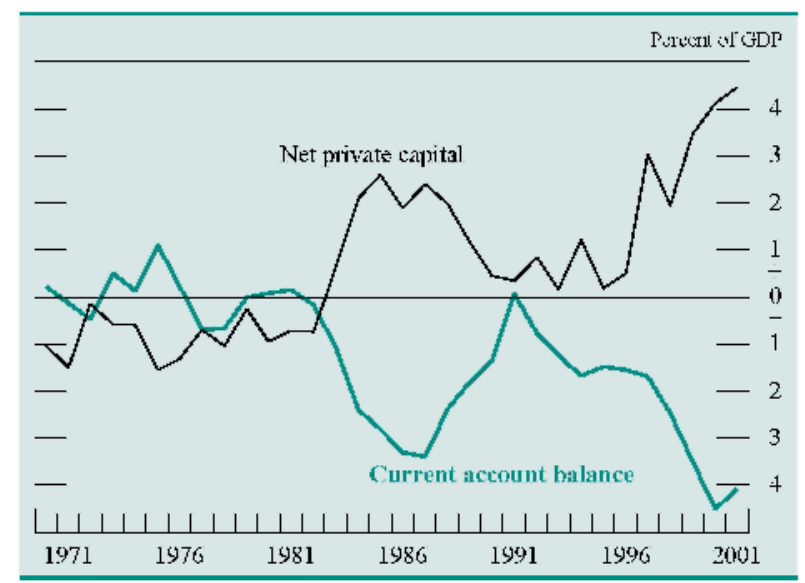

NoTE. The data are annual.

SoURCE. U.S. Department of Commerce, Bureau of Economic Analysis (BEA).

negative, indicating either small unrecorded net capital outflows or an underreporting of the current account deficit.

\section{MAJOR ECONOMIC INFLUENCES ON. U.S. INTERNATIONAL TRANSACTIONS}

Several factors had a significant influence on U.S. international transactions in 2001: cyclical movements in U.S. and foreign economic activity, a decline in primary commodity prices, movements in U.S. international price competitiveness, swings in the rates of return on real and financial assets at home and abroad, and the terrorist attacks of September 11.

\section{U.S. Economic Activity}

In 2001 the U.S. economy turned in its weakest performance in a decade, and the slowing pace of activity contributed to a decline in U.S. imports. Real gross domestic product increased at an annual rate of $3 / 4$ percent in the first half of the year and remained virtually stagnant in the second half (table 2). Although the effects of the weakening economy were broadly felt, the manufacturing sector was especially hard hit. Faced with slumping demand both in the United States and abroad, manufacturers cut production aggressively to limit excessive buildups of inventories relative to sales. In addition, businesses sharply reduced their investment spending with particularly dramatic cuts in outlays for high-technology equipment. Firms trimmed payrolls through most of the year, and by year-end the unemployment rate moved up $13 / 4$ percentage points, to around $53 / 4$ percent. Job losses were especially large following the terrorist attacks of September 11, which had extremely adverse effects on certain sectors of the economymost notably the air transportation and hospitality industries.

Growth of household spending slowed last year but remained sufficiently strong to provide an important source of support to overall final demand. Consumption spending was stimulated last year by lower interest rates, cuts in federal taxes, declining energy prices, and, in the autumn, higher spending on motor vehicles arising from automaker's aggressive marketing of financial incentives to consumers. After September 11, spending declined in certain travel- and tourism-related categories including air transportation, hotels and motels, and recreation services. Favorable mortgage interest rates helped sustain real expenditures on housing. In all, however, the slowing of household spending, combined with the sharp drop in business spending, led to a decline in real imports in 2001 .

\section{Foreign Economic Activity}

A substantial weakening of economic growth in foreign economies in 2001 contributed to a decline in U.S. exports. Early in the year, activity abroad was depressed by high oil prices, the global slump in the high-tech sector, and spillover from the U.S. economic slowdown. The September terrorist attacks further heightened economic uncertainty. The weakening in economic activity abroad prompted some foreign central banks to reduce interest rates and some foreign governments to take stimulative fiscal measures. Despite these actions, growth in foreign economies was near zero on average over the year (table 2).

Among the major foreign industrial economies, the weakest performer was Japan, where output declined nearly 2 percent and unemployment rose. The deterioration continued a decade-long pattern of poor economic performance. Private investment slumped as firms slashed capital spending amid a worsened outlook for profits. In addition, exports fell sharply; the drop in sales of high-tech products was particularly steep. Private consumption remained sluggish because of declines in household incomes. The scaling-back of the large public works programs of recent years more than offset the effect on growth from the additional spending contained in several supplemental budgets.

The Canadian economy, which had been growing at a rapid pace, slowed abruptly. Real GDP in Canada 
rose less than 1 percent last year after growth of more than 3 percent in 2000. A key factor in the slowing was the sharp drop-off in Canadian exports to the United States. An inventory correction depressed output, while consumption was buoyed by continued employment growth, tax cuts, and a housing boom.

The euro area eked out an increase in real GDP of less than 1 percent, a sharp slowing from the 3 percent increase in 2000. Activity was restrained by declines in fixed investment and inventory investment and a continuation of sluggish growth in consumption.

Growth in most emerging market economies in Asia and Latin America slowed sharply last year. Asian developing economies were particularly hard hit by the falloff in demand for their high-tech exports and by the slowing of activity among their industrialcountry trading partners. High-tech exports from the region began to decline late in 2000 . The emerging Asian economies particularly dependent on such exports-Korea, Taiwan, Malaysia, and Singaporewere among the first to slow in the recent global downturn, and real GDP growth in these economies turned negative in the latter part of 2000 or early in 2001. However, as 2001 neared conclusion, global high-tech demand appeared to stabilize, and mounting evidence suggested that the region was moving toward recovery. In China, the available data indicate that growth remained strong last year, notwithstanding some slowing of export growth; activity was supported by ongoing fiscal stimulus and record inflows of foreign direct investment.

Economic activity in the major Latin American economies weakened significantly in 2001. Real GDP in Mexico contracted steadily, with a sharp reduction in export demand from the United States contributing to a decline in confidence and a marked weakening of domestic demand. Accordingly, the drop in Mexico's exports was matched by an almost identical drop in its imports. The situation in Argentina, already difficult when the year began, deteriorated further; the country eventually defaulted on its debt and, in early 2002, abandoned its fixed exchange rate regime. By the end of the year, the Argentine economy was essentially in free fall, and real GDP declined nearly 10 percent for 2001. In Brazil, real activity also contracted; performance there was constrained by a severe drought and by spillovers from the crisis in Argentina that triggered a rapid tightening of monetary policy in an effort to defend the currency.

\section{Primary Commodity Prices}

Oi] prices declined significantly during 2001 from the unusually high levels that prevailed in 2000. The spot price of West Texas intermediate (WTI) crude decreased about $\$ 10$ per barrel during the year, with much of the decline occurring after September 11

2. Change in real GDP in the United States and abroad, 1998-2001

Percent, annual rate

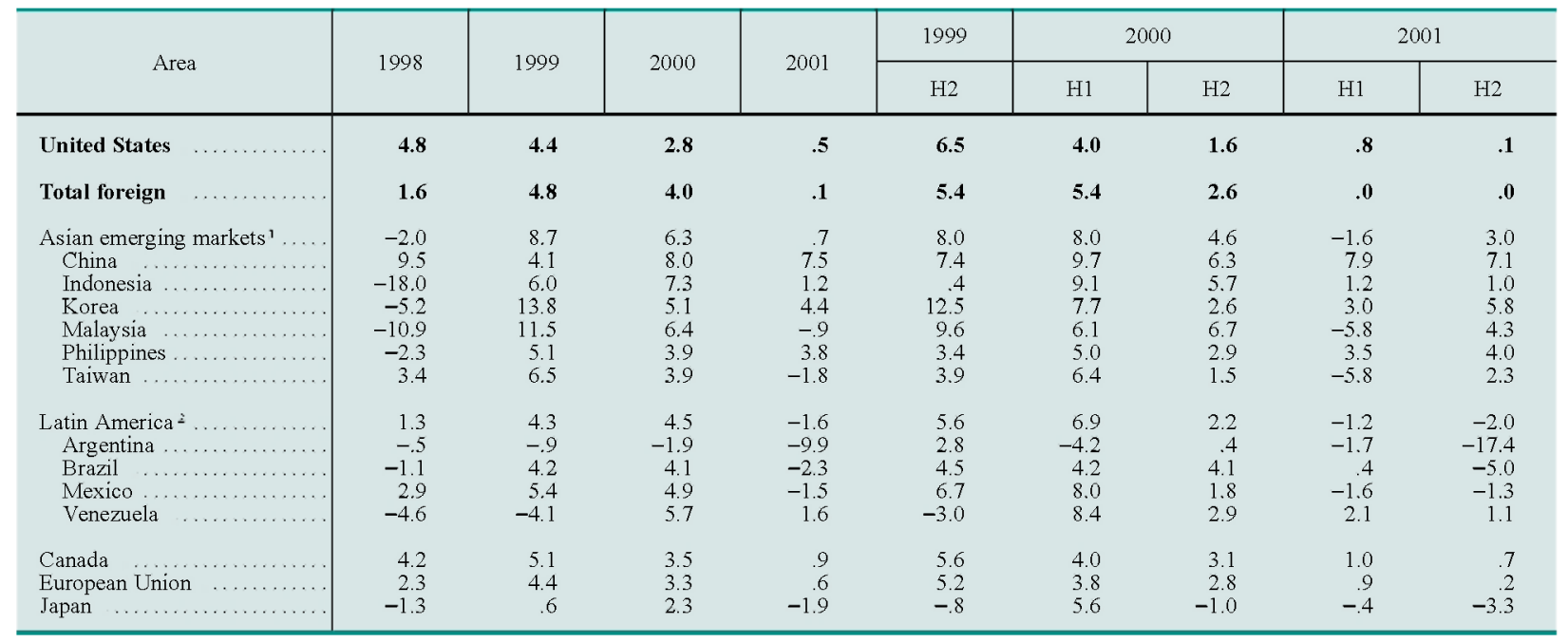

NoTE. Aggregate measures are weighted by moving bilateral shares in U.S. exports of merchandise. Annual data are four-quarter changes. Half-yearly data are calculated as Q4/Q2 or Q2/Q4 changes at an annual rate.

1 Weighted average of China, Hong Kong, Indonesia, Korea, Malaysia,

2 Weighted average of Argentina, Brazil, Chile, Colombia, Mexico, and Venezuela.

SOURCE. Various national sources

Philippines, Singapore, Taiwan, and Thailand. 


\section{Oil prices, $1986-2001$}

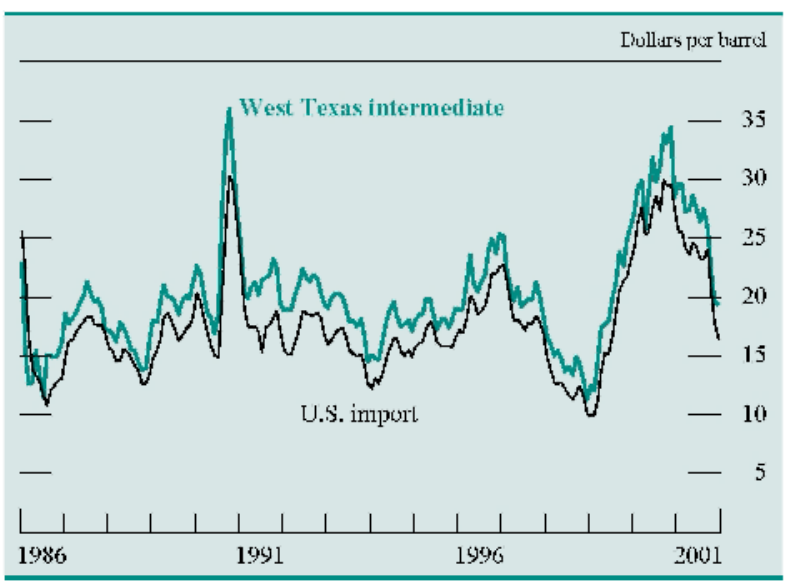

NoTE. The data are monthly.

SOURCE. Wall Street Journal and BEA.

(chart 2). During the first eight months of 2001, weakened demand for oil and increased non-OPEC supply were largely offset by OPEC production restraint, and the spot price of WTI averaged \$28 per barrel. After a brief, sharp uptick in oil prices in the wake of the terrorist attacks, oil prices dropped sharply in response to a decline in jet fuel consumption, weaker economic activity, and reassurances from Saudi Arabia that supply would be forthcoming. During the fourth quarter, some members of OPEC appeared unwilling to continue sacrificing market share to defend higher oil prices, and oil prices continued to drift lower. In late December, however, OPEC worked out an arrangement with several nonOPEC producers (Angola, Mexico, Norway, Oman,

3. Prices of world non-oil primary commodities, 1986-2001

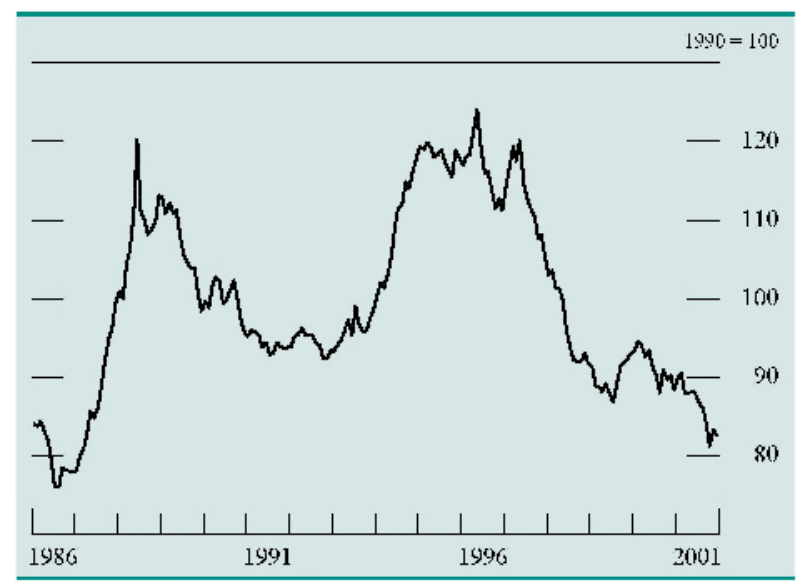

NOTE. The data are monthly.

SourCE. International Monetary Fund, International Financial Statistics, index of non-oil commodity prices in dollars. and Russia) in which OPEC agreed to reduce its production targets an additional 1.5 million barrels per day, and the other producers agreed to reduce oil supplies a total of 462,500 barrels per day.

Prices of non-oil primary commodities, which fell steadily through most of 2001, reached a fourteenyear low in October (chart 3). Prices stabilized near year-end as the prospect of improving global economic conditions led to a slight uptick in prices, especially in the cyclically sensitive categories of agricultural raw materials and metals. Prices of nonoil primary commodities had fallen from the onset of the Asian crisis, in 1997, through the first half of 1999 , a period of weak global demand for these commodities and large increases in supply that emanated from the high prices of the mid-1990s (especially for agricultural products). Prices rebounded slightly in the second half of 1999 with the pickup in global economic growth, but they subsequently fell through most of 2000 as the dollar climbed and global economic activity decelerated.

\section{U.S. Price Competitiveness}

Changes in the price competitiveness of U.S. exportand import-competing industries depend on the relative movements of inflation rates here and abroad and on changes in the foreign exchange value of the dollar. In the United States, a sharp drop in energy prices reduced the inflation rate during 2001 (chart 4). Inflation of core consumer prices (consumer prices less food and energy items) leveled off and, by some measures, moved lower last year. Also helping to

4. Change in U.S. and foreign consumer price indexes, 1998-2001

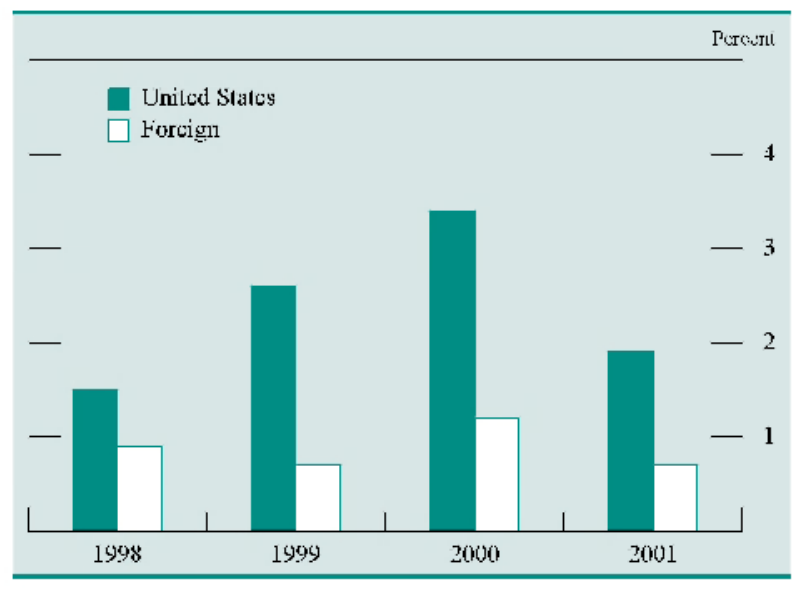

NoTE. Fourth quarter to fourth quarter. The index for foreign countries is a weighted average of foreign G-7 countries. The weights are shares in foreign GDP. 
keep a lid on core consumer prices were weakening economic activity, the indirect effects of falling energy prices on firm's costs, the sustained vigorous productivity performance by U.S. workers, and continued strong competitive pressures.

Foreign inflation also fell in 2001. Inflation rates in the foreign Group of Seven (G-7) countries were, on average, lower than U.S. rates (chart 4). The easing of average inflation abroad, as in the United States, reflected the weakness of activity and the net decline in global oil prices over the year. In addition, all major foreign industrial countries operated below their estimated potential rates of output (some considerably so). Passthrough effects from the depreciation of exchange rates in Canada, the United Kingdom, and the euro area were barely perceptible.

The dollar's average foreign exchange value grew stronger through most of the year, appreciating $31 / 4$ percent on a real trade-weighted basis in terms of an index of a broad group of U.S. trading partners (chart 5). The dollar continued to rise despite mounting evidence of weakening U.S. economic activity and a significant easing of monetary policy by the Federal Open Market Committee. Market participants may have felt that the falloff in economic growth in foreign economies and expectations that the United States offered stronger prospects for economic growth in the future outweighed disappointing U.S. economic performance in the near term. The dollar's average foreign exchange value against the currencies of other major industrial countries recorded a net increase of 8 percent over the year as a whole. The dollar also strengthened, but by a lesser

5. Foreign exchange value of the U.S. dollar, 1990-2001

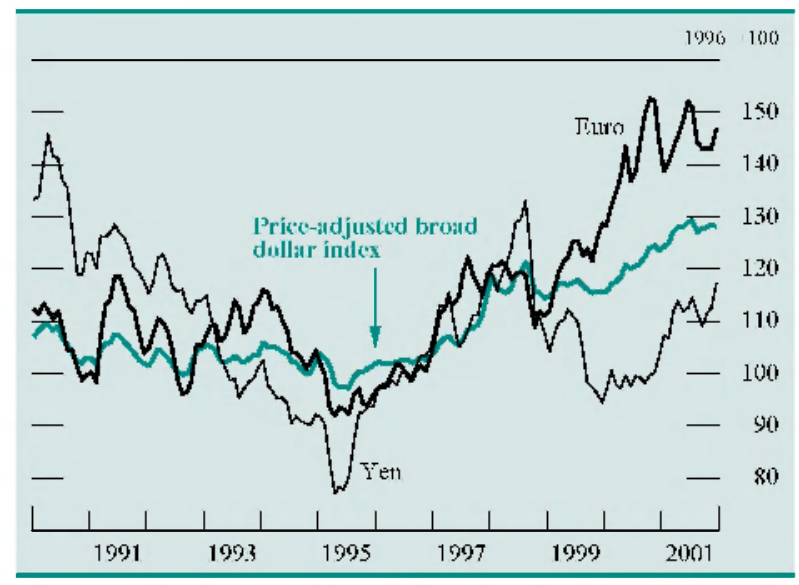

Note. Foreign currency units per dollar. The broad index covers a large group of important U.S. trading partners. For data before January 1999, the restated German mark is used for the euro exchange rate. The data are monthly. amount, against an index of the currencies of the most important developing-country trading partners of the United States.

The magnitude of the dollar's appreciation differed across the major currencies. The dollar showed particular strength against the Japanese yen, appreciating 15 percent. The weakness of the yen reflected ongoing structural problems in the Japanese economy and its relapse into recession. Relative to the euro, the dollar appreciated more than 5 percent, on balance, over the course of last year. The dollar's movements against the euro appear to have been mainly influenced by market perceptions of the strength of economic activity in the United States relative to that in the euro area. In the early part of the year, the euro weakened as evidence mounted that the economic slowdown that was already apparent in the United States as the year began was also taking hold in Europe. During the summer, the euro rose against the dollar as market participants appeared to revise downward their expectation of an early U.S. recovery. The euro declined later in the year on signs of a further weakening of activity in Europe. Relative to the Canadian dollar, the dollar appreciated 6 percent in 2001, a move reflecting the depressed level of primary commodity prices.

Against a weighted average of the currencies of developing-country trading partners, the dollar appreciated more than 2 percent in real terms. The dollar appreciated $3 \frac{1}{2}$ percent against a weighted average of Asian developing countries, whose economies were particularly depressed. The dollar appreciated 1 percent on a trade-weighted average basis against the currencies of Latin American trading partners, but it depreciated 5\%,2 percent against the Mexican peso. The contrary move against the peso apparently reflected a view in the market that Mexico's recent success in significantly reducing inflation would persist.

\section{DEVELOPMENTS IN U.S. TRADE IN GOODS AND SERVICES}

The U.S. trade deficit in goods and services was noticeably smaller in 2001 than in 2000 (table 3 ). The narrowing of the external balance primarily reflected the retarding effect on imports of the sharp slowdown in economic growth in the United States; that effect exceeded the drag on exports arising from slower economic growth abroad and the increasing price competitiveness of foreign goods as the dollar continued to appreciate. 


\section{Exports}

The value of exports of goods and services fell $\$ 61$ billion in 2001 after a rather large increase in 2000 (table 3). Service receipts declined 3 percent after a rise of $7 \frac{1}{4}$ percent in 2000 ; much of the decline was in receipts from foreign travelers in the United States because travel and tourism plunged after the terrorist attacks of September 11. Receipts from foreigners for other services changed little, on balance, over the year.

The value of goods exports declined $61 / 2$ percent after having expanded 13 percent in 2000 . The falloff affected almost all major categories of goods; the largest moves by far, however, were in high-tech capital goods and other machinery, a slump reflecting the effect of the global slowdown on investment in general and especially in spending on high-tech products. The decline in exported industrial supplies was mostly accounted for by a fall in prices, but quantities also decreased as industrial production declined in most of the U.S. principal trading partners. Although exports of automotive products fell during 2001 as well, shipments of automotive products rose during the second and third quarters (especially for parts to Canada destined ultimately to be used in U.S. markets and for vehicles to Canada), an increase reflecting the resilience of the North American consumer. Two categories of exports rose during 2001-aircraft; and foods, feeds, and beverages. The increase in aircraft exports reflected continued strong deliveries to developing countries, especially Singapore, China, and Brazil. Deliveries to Canada rose, while exports to Western Europe and Japan fell. The increase in exports of foods, feeds, and beverages was primarily driven by higher shipments to Latin America, especially Mexico.

The widespread nature of the economic slowdown caused the value of exported goods to decline for all major market destinations (table 4). The bursting of

3. U.S. international trade in goods and services, 1998-2001

Billions of dollars except as noted

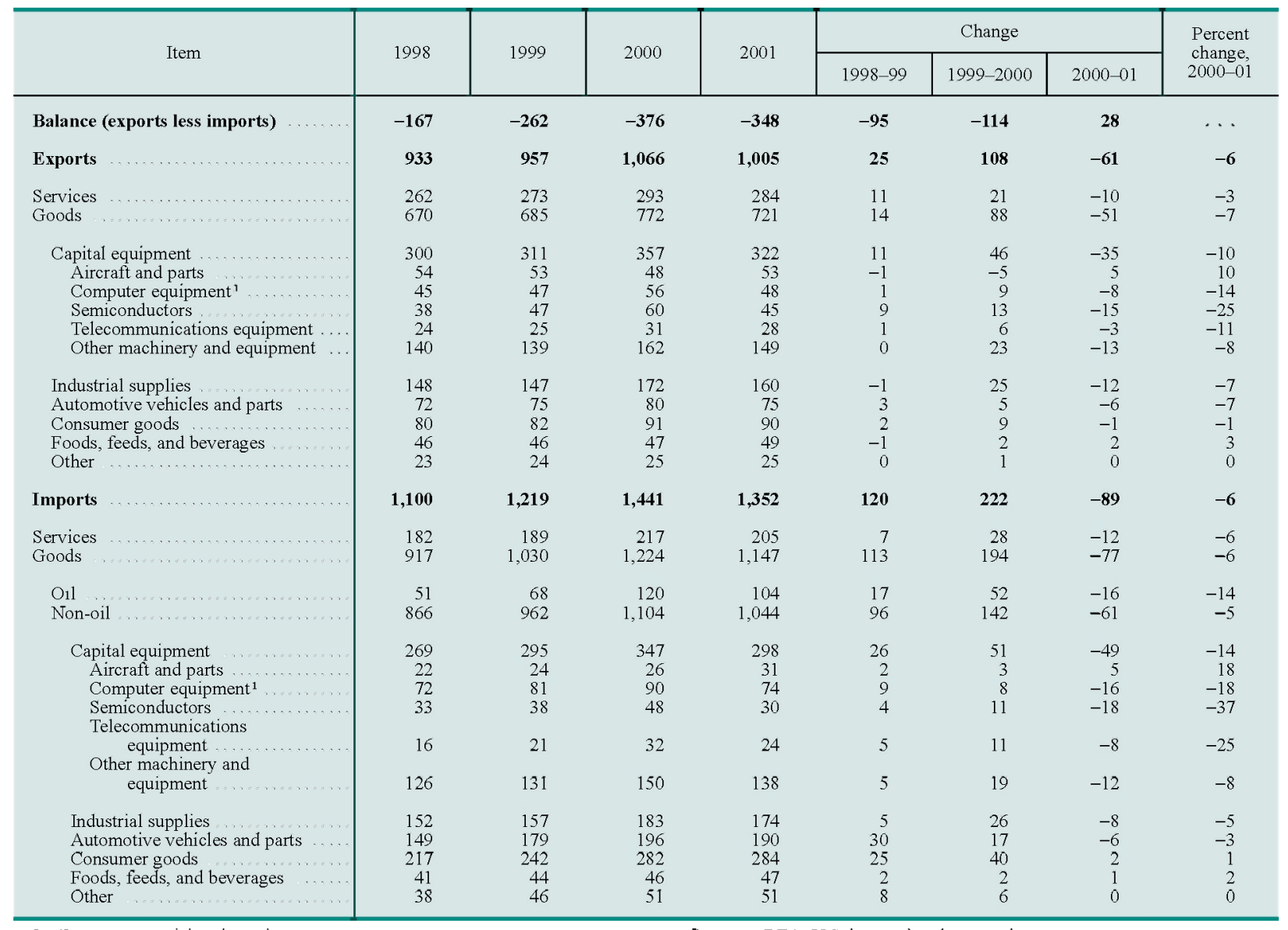

1. (omput:ts, periphistals, and parts.

Vol ipplicalis: 
4. Distribution of U.S. exports of goods, by selected regions and countries, 1998-2001 Billions of dollars

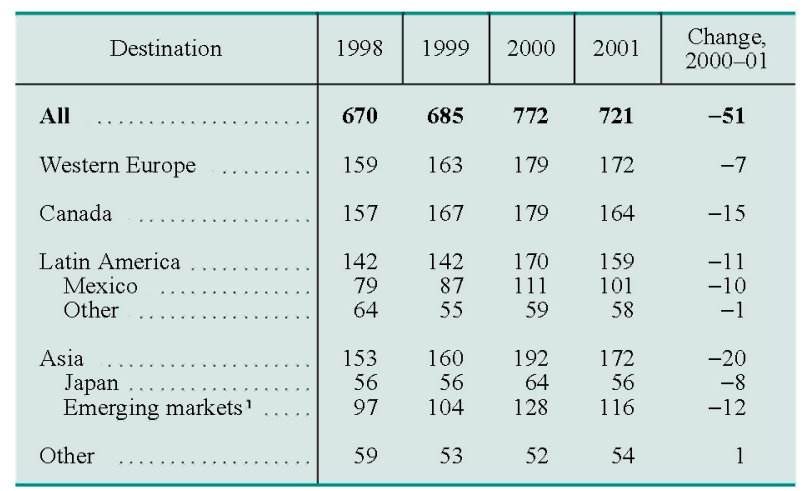

1. China, Hong Kong, Indonesia, Korea, Malaysia, Philippines, Singapore, Taiwan, and Thailand.

SoURCE. BEA, U.S. international transactions accounts.

the high-tech bubble concentrated the largest decline in total goods exports in those countries in Asia (excluding Japan) that are most heavily invested in high-tech manufacturing. Exports to these countries

5. Change in the quantity of U.S. exports and imports of goods and services, 1998-2001

Percent

\begin{tabular}{|c|c|c|c|c|}
\hline Item & 1998 & 1999 & 2000 & 2001 \\
\hline Exports & 2 & 5 & 7 & -11 \\
\hline Services & 3 & 2 & 4 & -7 \\
\hline Goods ... & 2 & 6 & 8 & -13 \\
\hline Capital equipment ${ }^{1}$ & 4 & 7 & 13 & -20 \\
\hline Aircraft and parts $\ldots$ & 47 & -17 & -14 & -3 \\
\hline Computer equipment" & 8 & 14 & 23 & -23 \\
\hline Semiconductors . ................ & 9 & 35 & 27 & -35 \\
\hline Other machinery and equipment $\ldots$ & -8 & 8 & 14 & -19 \\
\hline Industrial supplies $\ldots \ldots \ldots \ldots$ & -2 & 6 & 7 & -7 \\
\hline Automotive vehicles and parts & -3 & 2 & 0 & -6 \\
\hline Consumer goods $\ldots \ldots \ldots \ldots$ & 3 & 6 & 6 & -6 \\
\hline Foods, feeds, and beverages .......... & -3 & 3 & 2 & 5 \\
\hline Other $\ldots \ldots \ldots \ldots \ldots \ldots \ldots \ldots$ & 15 & 1 & 6 & -13 \\
\hline Imports & 11 & 11 & 11 & -9 \\
\hline Services $\quad \ldots \ldots \ldots$. & 8 & 3 & 12 & -15 \\
\hline Goods $\ldots \ldots \ldots \ldots \ldots \ldots \ldots \ldots \ldots$ & 11 & 13 & 11 & -7 \\
\hline O1l $\ldots$ & 4 & -3 & 12 & 0 \\
\hline Non-oil $\ldots \ldots \ldots \ldots \ldots \ldots \ldots \ldots \ldots \ldots$ & 12 & 15 & 11 & -8 \\
\hline Capital equipment ${ }^{1}$. & 11 & 18 & 17 & -21 \\
\hline Aircraft and parts ..... & 31 & -2 & 22 & 2 \\
\hline Computer equipment" & 26 & 25 & 14 & -14 \\
\hline Semiconductors $\ldots .$. & -9 & 34 & 22 & -51 \\
\hline $\begin{array}{l}\text { Other machinery and } \\
\text { equipment } \ldots \ldots \ldots \ldots \ldots \ldots\end{array}$ & 6 & 15 & 17 & -20 \\
\hline Industrial supplies $\ldots \ldots \ldots \ldots \ldots \ldots$ & 9 & 8 & 1 & -3 \\
\hline Automotive vehicles and parts .... & 16 & 15 & 2 & -2 \\
\hline Consumer goods ................ & 10 & 17 & 16 & -5 \\
\hline Foods, feeds, and beverages $\ldots \ldots$ & 6 & 11 & 6 & 4 \\
\hline Other $\ldots \ldots \ldots \ldots \ldots \ldots \ldots \ldots \ldots \ldots$ & 25 & 9 & 16 & 0 \\
\hline
\end{tabular}

NoTE. Quantities are measured in chained (1996) dollars and change is from fourth auarter to fourth auarter.

1. Data for telecommunications equipment not separately calculated.

2. Computers, peripherals, and parts.

SourCE. BEA, national income and product accounts; and the Federal Reserve Board. (excluding Japan) account for 16 percent of U.S. goods exports. Exports of goods to Canada (22 percent of all U.S. goods exports), also fell noticeably, primarily in the capital goods and automotive products categories. The decline to Mexico (14 percent of U.S. exported goods) was primarily in industrial supplies and capital goods and reflected the fall in Mexican industrial production. In contrast, exports of automotive parts to Mexico (mostly shipped back to the United States as part of assembled vehicles) declined only marginally as U.S. demand for motor vehicles held up and exports of vehicles rose slightly.

In Western Europe, the economic downturn, although steep, was less severe than in East Asia and the Western Hemisphere; hence, exports to Western Europe were somewhat less affected last year and fell less than 4 percent. The decline, which was entirely in capital goods and industrial supplies, was driven by declines in industrial production. Increases were recorded in U.S. exports of consumer goods, automotive products and foods.

The quantity of exports fell 11 percent in 2001 (Q4 to Q4) after having posted increases the previous three years (table 5). All major categories of exports

6. Change in the prices of U.S. exports and imports of goods and services, 1998-2001

Percent

\begin{tabular}{|c|c|c|c|c|}
\hline Item & 1998 & 1999 & 2000 & 200 \\
\hline Exports & -3 & 1 & 2 & -1 \\
\hline $\begin{array}{l}\text { Services } \\
\text { Goods }\end{array}$ & $\begin{array}{r}0 \\
-4\end{array}$ & $\begin{array}{l}2 \\
0\end{array}$ & $\begin{array}{l}4 \\
1\end{array}$ & $\begin{array}{r}0 \\
-2\end{array}$ \\
\hline 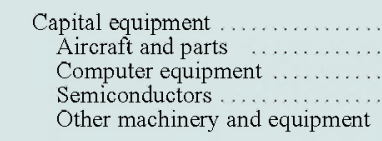 & $\begin{array}{r}-3 \\
1 \\
-13 \\
-6 \\
0\end{array}$ & $\begin{array}{r}-1 \\
3 \\
-7 \\
-4 \\
0\end{array}$ & $\begin{array}{r}0 \\
5 \\
-4 \\
-5 \\
1\end{array}$ & $\begin{array}{r}-1 \\
5 \\
-5 \\
-5 \\
0\end{array}$ \\
\hline 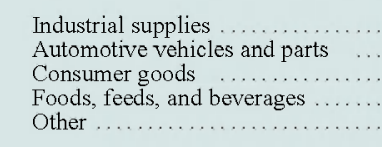 & $\begin{array}{r}-7 \\
0 \\
0 \\
-9 \\
-3\end{array}$ & $\begin{array}{r}4 \\
1 \\
0 \\
-4 \\
1\end{array}$ & $\begin{array}{l}4 \\
1 \\
0 \\
0 \\
1\end{array}$ & $\begin{array}{r}-7 \\
0 \\
0 \\
0 \\
-1\end{array}$ \\
\hline Imports & -5 & 4 & 3 & -6 \\
\hline $\begin{array}{l}\text { Services } \\
\text { Goods }\end{array}$ & $\begin{array}{r}0 \\
-6\end{array}$ & $\begin{array}{l}3 \\
4\end{array}$ & $\begin{array}{l}0 \\
3\end{array}$ & $\begin{array}{r}1 \\
-7\end{array}$ \\
\hline $\begin{array}{l}\text { Oil ...... } \\
\text { Non-oil }\end{array}$ & $\begin{array}{r}-36 \\
-4\end{array}$ & $\begin{array}{l}94 \\
-1\end{array}$ & $\begin{array}{r}32 \\
1\end{array}$ & $\begin{array}{r}-36 \\
-4\end{array}$ \\
\hline $\begin{array}{l}\text { Capital equipment } \ldots . . . \\
\text { Aircraft and parts ..... } \\
\text { Computer equipment } \\
\text { Semiconductors ...... } \\
\text { Other machinery and } \\
\text { equipment ........ }\end{array}$ & $\begin{array}{r}-6 \\
2 \\
-16 \\
-8 \\
-1\end{array}$ & $\begin{array}{r}-4 \\
2 \\
-11 \\
-3 \\
-1\end{array}$ & $\begin{array}{r}-2 \\
4 \\
-5 \\
-2 \\
-1\end{array}$ & $\begin{array}{r}-4 \\
3 \\
-12 \\
-3 \\
-1\end{array}$ \\
\hline $\begin{array}{l}\text { Industrial supplies ............ } \\
\text { Automotive vehicles and parts } \\
\text { Consumer goods ............ } \\
\text { Foods, feeds, and beverages ... } \\
\text { Other }\end{array}$ & $\begin{array}{r}-7 \\
0 \\
-1 \\
-3 \\
0\end{array}$ & $\begin{array}{r}4 \\
1 \\
-1 \\
-3 \\
0\end{array}$ & $\begin{array}{r}11 \\
1 \\
-1 \\
-2 \\
1\end{array}$ & $\begin{array}{r}-14 \\
0 \\
-1 \\
-2 \\
-1\end{array}$ \\
\hline
\end{tabular}

NoTE. Change is from fourth quarter to fourth quarter; price indexes are chain-weighted. See also notes to table 5 . 
declined except that of foods, feeds, and beverages, which increased.

Export prices fell $11 \frac{1}{2}$ percent last year (table 6). The price declines accelerated over the course of the year as economic growth slowed both at home and abroad. The price of total merchandise exports fell about 2 percent, including a drop of about $4 \frac{1}{2}$ percent in the prices of exports of computers and semiconductors. A particularly sharp fall (about 7 percent) was recorded in the industrial supplies category. Prices of aircraft and parts rose 5 percent; prices in other major categories were unchanged over the course of the year. Prices of services fell a small amount, particularly at the end of the year, as demand for travel fell off in the wake of the events of September 11 .

\section{Imports}

The value of imports fell 6 percent in 2001 after a rise of 18 percent in 2000; declines were recorded in nearly all major categories (table 3 ). The nominal value of service payments dropped $5 \frac{1 / 2}{2}$ percent last year. ${ }^{\perp}$ The plunge in payments for travel and passenger fares after September 11 held down total real service payments, bringing their level in the fourth quarter 15 percent below that in the second quarter. ${ }^{2}$ The value of imported goods fell 6 percent last year; much of the decrease in capital goods (computers, semiconductors, telecommunications equipment, and other machinery) reflected the central role played by the fall in investment in the U.S. economic slowdown. Imports of automotive products and industrial supplies declined as well. Imports of consumer goods and foods were little changed, as U.S. household spending was reasonably well maintained.

\section{Oil Imports}

The value of U.S. imports of crude oil and petroleum products fell more than one-third over the four quar-

1. The "insurance payment" component of imported services is calculated as the value of premiums paid to foreign companies less the amount of: losses recovered from foreign companies. In the third quarter, the recorded insurance payment was negative because the estimated size of losses to be recovered from the attacks of September 11 far exceeded the amount paid for insurance premiums. Under the accounting standards for the balance of payments and the national income and product accounts (NIPA), the entire amount of an insurance payment is recorded in the quarter in which the incident occurred.

2. 'According to NIPA accounting, the value of the one-time insurance payments by foreign insurers is not reflected in NIPA real imports of services. The deflator for service imports was adjusted down for the third quarter to offset the lower value of service imports; the deflator returned to its usual value in the fourth quarter. ters of 2001 and 14 percent on a year-over-year basis (table 3). Oil import prices fell sharply; the quantity of imported oil was little changed during the year (tables 5 and 6). A number of factors combined to cut U.S. domestic demand for oil, which declined more than 3 percent: weakness in economic activity, reduced airline schedules, the substitution back to natural gas as gas prices retracted from record high levels, and unusually warm weather late in the year. The stability of both imports and domestic production, in conjunction with lower domestic fuel demand, allowed a recovery of oil inventories from the historically low levels that prevailed in 2000 and early 2001 .

\section{Non-Oil Imports}

The quantity of non-oil imports fell 8 percent in 2001 (Q4 to Q4, table 5). A sharp decline of 21 percent in real expenditures on imported capital equipment

\section{Change in industrial production, 1977-2001}

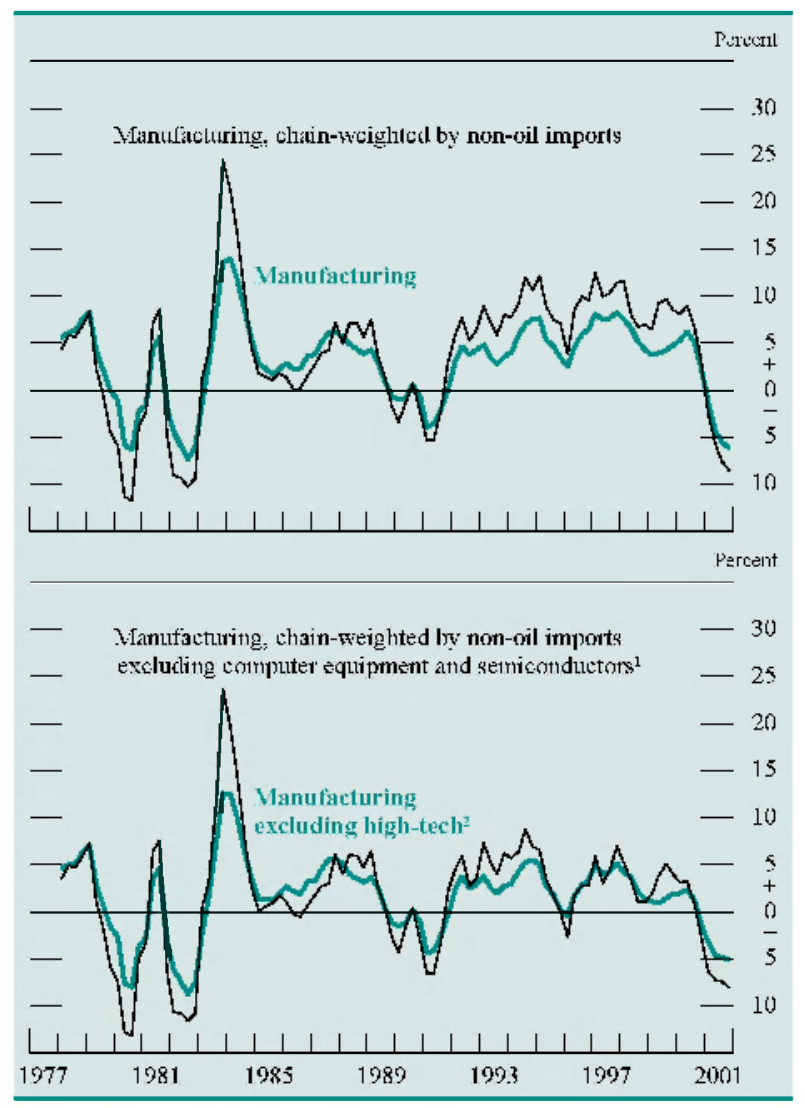

NotE. Change is for four quarters.

1. Computer equipment consists of computers, peripherals, and parts.

2. Iligh-tech goods consist of computers and oftice equipment, semiconduclors, and communications cquipment. 
reflected the fall in U.S. investment expenditures. In the wake of last year's depression in the semiconductor industry, imports of semiconductor products fell 51 percent after having registered double-digit gains in the previous two years. Similarly, in line with the fall of U.S. domestic expenditures on high-tech products in 2001, imports of computer equipment, which had registered strong gains the previous three years, declined 14 percent. U.S. consumer expenditures held up reasonably well during the economic slowdown last year. Real expenditures on imports of consumer goods fell a relatively mild 5 percent, mostly because of a draw-down in retail inventories.

U.S. non-oil imports, and tradeable goods in general, are particularly cyclically sensitive. This cyclical sensitivity appears to reflect the nature of demand for importable goods, including import-competing goods produced domestically. One way to quantify this sensitivity is to aggregate the components of the industrial production index for manufacturing using non-oil import weights rather than the index with the customary domestic value added weights. The value of the index calculated using non-oil import weights rises more rapidly during booms and falls more steeply during downturns than does the index computed using value added weights (chart 6 , top panel). This relationship persists even if one excludes the high-tech products believed to have played a key role in the most recent economic slump (chart 6, bottom panel). The same factors behind the sharp drop in demand for domestically produced tradeable goods evident last year are almost certainly responsible for the corresponding drop in imports.

The average price of non-oil goods imports was down about 4 percent, as prices of high-tech equipment (computers and semiconductors) continued to trend down, while prices of other goods generally fell by smaller amounts (table 6). The largest price decline among the major categories was in industrial supplies, whose price drop of about 14 percent more than reversed the previous year's increase. Prices of service imports rose 1 percent on average over the course of the year. The weakness in import prices largely reflected the strength of the dollar, which rose about 3 percent on average on an importweighted basis in 2001; dollar appreciation more than offset a moderate increase in foreign prices. Sharp declines in commodity prices in the face of sluggish global economic demand also contributed to the reduction in the price of imported goods.

\section{DEVELOPMENTS IN THE NONTRADE CURRENT ACCOUNT}

The major components of the current account other than trade in goods and services are investment income and unilateral transfers.

\section{Investment Income}

Net investment income is the difference between the amount that U.S. residents earn on their direct and portfolio investments abroad (receipts) and the amount that foreigners earn on their direct and portfolio investments in the United States (payments). Payments and receipts are determined by both the size of the investments held and the rates of return earned on these investments. Foreign investments in the United States greatly exceed U.S. investments abroad, and since 1998, payments have exceeded receipts. Last year, slower economic growth and lower interest rates reduced the rates of return on both direct and portfolio investments. As a result, payments and receipts both declined (table 7). On balance, however, payments fell less than receipts as new foreign investment in the United States greatly exceeded new U.S. investment abroad (chart 7).

7. U.S. international investment: Receipts and payments, 1997-2001

Billions of dollars

\begin{tabular}{|c|c|c|c|c|c|c|}
\hline Item & 1997 & 1998 & 1999 & 2000 & 2001 & $\begin{array}{l}\text { Change, } \\
2000-01\end{array}$ \\
\hline Net investment income & 14 & -1 & -9 & -10 & -14 & -4 \\
\hline $\begin{array}{l}\text { Direct investment } \\
\text { Net income } \\
\text { Receipts } \\
\text { Payments } . . . . . . \\
\end{array}$ & $\begin{array}{r}72 \\
115 \\
43\end{array}$ & $\begin{array}{r}66 \\
104 \\
38\end{array}$ & $\begin{array}{r}67 \\
124 \\
57\end{array}$ & $\begin{array}{r}81 \\
149 \\
68\end{array}$ & $\begin{array}{r}95 \\
133 \\
37\end{array}$ & $\begin{array}{r}14 \\
-17 \\
-31\end{array}$ \\
\hline $\begin{array}{l}\text { Pontfolio investment } \\
\text { Net income } \ldots . . . \\
\text { Receipts } \\
\text { Payments } \ldots . . . \\
\end{array}$ & $\begin{array}{l}-59 \\
143 \\
202\end{array}$ & $\begin{array}{l}-67 \\
153 \\
221\end{array}$ & $\begin{array}{l}-76 \\
159 \\
235\end{array}$ & $\begin{array}{l}-91 \\
201 \\
292\end{array}$ & $\begin{array}{r}-109 \\
159 \\
268\end{array}$ & $\begin{array}{l}-18 \\
-43 \\
-24\end{array}$ \\
\hline
\end{tabular}

SouRCE. BEA, U.S. international transactions accounts 
7. U.S. net international investment: Position and income, 1980-2001

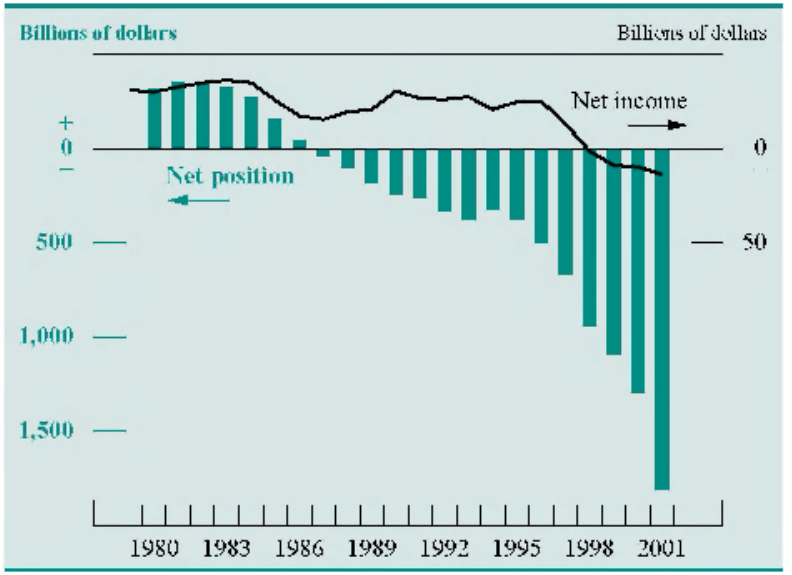

Note. The data are annual. The net position data are averages of the end-offyear positions for the current and previous years. The year-end position for 2001 was constructed by adding the recorded portfolio investment flows during 2001 to the recorded year-end position for 2000 . The net position excludes U.S. holdings of gold and foreign holdings of U.S. currency.

SOURCE. BEA and the Federal Reserve Board.

\section{Direct Investment Income}

Net direct investment income-receipts from U.S. direct investment abroad less payments on foreign direct investment in the United States-increased $\$ 14$ billion in 2001 (table 7). Both direct investment receipts (from abroad) and earnings on direct investment in the United States declined last year.

The $\$ 17$ billion decline in receipts reflected the slowdown in economic growth abroad and the appreciation of the dollar. The weakness in growth abroad reduced profits, and the appreciation of the dollar depressed the dollar value of profits earned in foreign currencies. These two forces offset the effect of a rising stock of direct investment assets. The decline in receipts was geographically widespread but was greatest in Europe, particularly in the United Kingdom. Most industries were affected adversely, but the earnings of affiliates in manufacturing and finance (excluding banks) were particularly hard hit. In addition, the decline in oil prices during the second half of last year held down the profitability of U.S.based international energy corporations. The falloff in receipts reduced the rate of return on the direct investment position abroad to 8.7 percent for the year-considerably below the robust 10.8 percent rate of 2000 (chart 8 ).

The recession in the U.S. economy cut payments $\$ 31$ billion-a decline that in both absolute and relative terms was much larger than that for receipts. Although the stock of foreign direct investment assets
8. U.S. direct investment abroad: Position and receipts, 1980-2001

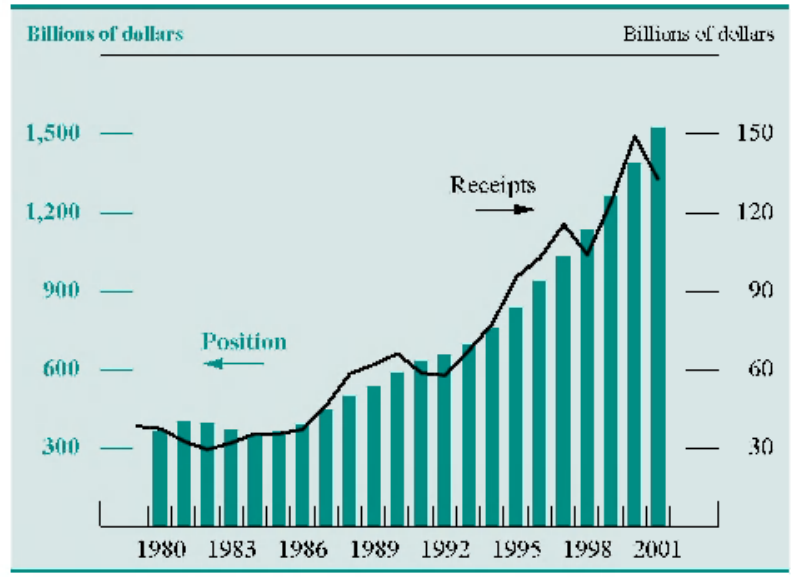

NOTE. The data are annual. The net position data are averages using the current-cost measures as of year-end for the current and previous years. The year-end position for 2001 was constructed by adding the recorded direct investment capital flows and current-cost adjustment during 2001 to the recorded year-end position for 2000 .

SOURCE. BEA and the Federal Reserve Board.

in the United States rose, the effect on payments was more than offset by the effect of the depressed level of U.S. economic activity on profits and the effect of: the decline in oil prices on the profits of international energy companies. The profits of every industry suffered, but manufacturing and finance were hardest hit, while payments from banking and retail trade were almost flat. The recession almost halved the rate of return on the direct investment position between 2000 and 2001 - from 5.5 percent to 2.6 percent (chart 9).

In addition to the cyclical factors that in 2001 lowered direct investment payments more than receipts, the large positive balance on direct invest-

9. Foreign direct investment in the United States: Position and payments, 1980-2001

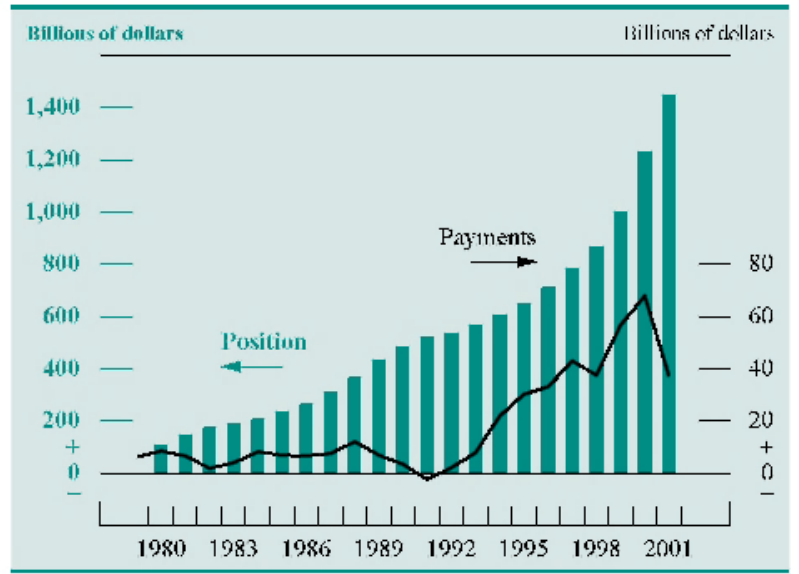

NoTE. See notes to chart 8 . 
ment income was also attributable to the longstanding lower rate of return on foreign direct investment in the United States. The rate of return on foreign direct investment in the United States is lower than that on U.S. direct investment abroad or on U.S. resident assets of U.S.-owned firms. A number of factors explain the differences between the rate of return earned on foreign direct investment and that on U.S. resident assets of U.S.-owned firms: higher debt-equity ratios and depreciation rates, the industrial composition of foreign direct investment in the United States, and the relatively lower level of royalties and dividends received by foreign direct investment in the United States. ${ }^{3}$

\section{Portfolio Investment Income}

U.S. residents earn income in the form of interest and dividends on their financial assets abroad. Similarly, foreigners earn income on their holdings of U.S. financial assets. These earnings are calculated by the Bureau of Economic Analysis (BEA) of the Department of Commerce on the basis of estimates of holdings, dividend-payout ratios, and interest rates. Investment income does not include capital gains associated with changes in securities prices.

3. See Harry Grubert, "Another Look at the Low Taxable Income of Foreign-Controlled Companies in the United States," OTA Paper 74, U.S. Department of the Treasury, October 1997.

\section{Net portfolio investment:}

Position and income, 1980-2001

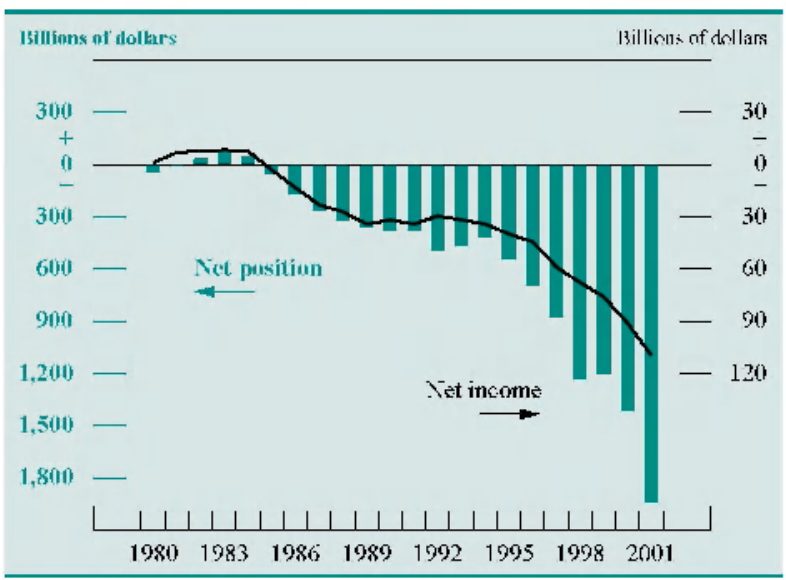

Note. The data are annual. The net position data are Federal Reserve Board estimates of the average position during the year. Through 2000 these are based on quarterly financial flows and year-end position estimates published by the BEA. For 2001, the average is based on year-end 2000 position data and quarterly financial flows during 2001. The net position excludes U.S. gold holdings and foreign holdings of U.S. currency.

SOURCE. BEA and the Federal Reserve Board.
Although portfolio income is affected by changes in interest rates and the composition of the assets held, the primary determinant of net portfolio payments is the net portfolio asset position (chart 10) because the rates of return on portfolio investments here and abroad are roughly similar (chart 11). Net portfolio income turned negative in 1985 when the net portfolio asset position turned negative. The marked decline in interest rates last year tended to reduce both payments and receipts and to narrow the investment income balance. This interest rate effect was more than offset, however, by a significant decline in the net portfolio position. The negative net income balance widened $\$ 18$ billion, to $\$ 109$ billion (table 7).

\section{Unilateral Transfers}

Unilateral transfers include government grant and pension payments as well as private transfers to and from foreigners. In 2001, net unilateral transfers recorded a deficit of $\$ 50.5$ billion, nearly $\$ 4$ billion less than in 2000. A decline of $\$ 5$ billion in government grants offset the $\$ 1$ billion increase in private remittances.

\section{FINANCIAL AND CAPITAL ACCOUNT. TKANSACTIONS.}

The counterpart of the deficit on the U.S. current account in 2001 was a net financial inflow of foreign saving. The slowing of U.S. and foreign economic growth over the course of last year had noticeable effects on the composition of U.S. capital flows,

11. Rate of return on U.S. portfolio investments, 1980-2001

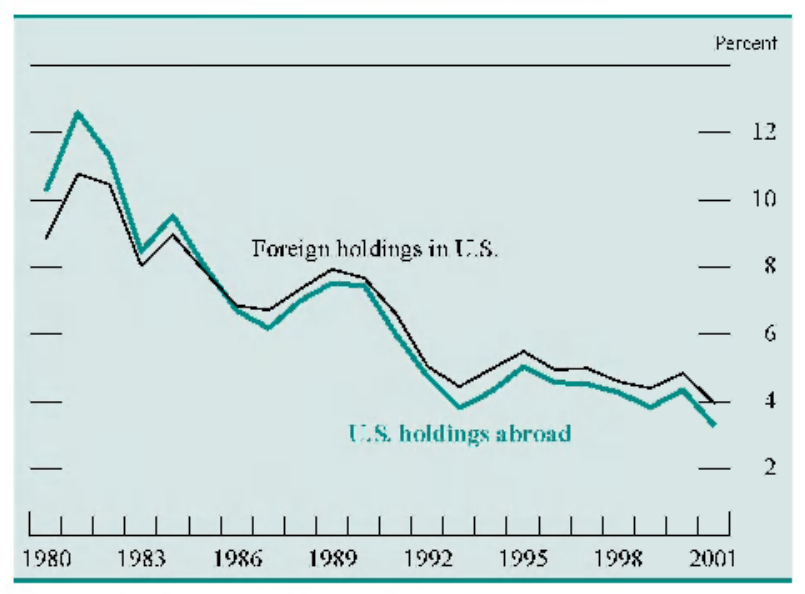

NoTE. The data are annual. 
especially when the extent of the slowing became more apparent in the second half of the year. On balance, the inflows of net private capital were at the unprecedented pace of $\$ 455$ billion (table 8 ).

For private securities transactions, the first half of the year was, for the most part, a continuation of 2000 . U.S. investors increased their demand for foreign equities, buying a net of $\$ 82$ billion, but continued to shun foreign bonds. Foreign investors purchased a record $\$ 281$ billion of U.S. securities. U.S. corporate bonds attracted record high inflows on the heels of record issuance. Strong demand for U.S. agency debt continued, as Fannie Mae and Freddie Mac continued to pursue active issuance calendars while developing their benchmark programs. Although the weight of sagging U.S. equity prices slowed acquisition of U.S. equities, the amount purchased was still robust. The one noticeable difference between the first half of last year and 2000 was a slowing of foreigners' net sales of Treasuries, from $\$ 53$ billion to $\$ 8$ billion.

The pattern changed in the second half of the year as the slowdown in U.S. and foreign economic growth became apparent and as the events of September caused global investors to rethink strategies. U.S. investors appeared to recoil from foreign markets: The modest but steady acquisition of foreign securities over the past few years almost turned to net sales in the second half of the year, when small purchases of foreign equities ( $\$ 28$ billion) were substantially offset by sales of foreign bonds ( $\$ 13$ billion). At the same time, foreign portfolio investment in the second half of the year seemed driven in part by flight-toquality considerations. Highly rated U.S. securities benefited from these considerations, as the latter half of the year saw strong net purchases of Treasuries and agency securities. Foreigners paused in their acquisition of U.S. corporate stocks and bonds in the third quarter but resumed strongly in the fourth quarter, perhaps because they believed that the U.S. economy would recover before major foreign economies would.

The changing economic climate also affected direct investment capital flows. During 2000, foreign direct investment in the United States averaged more than $\$ 70$ billion per quarter. These flows slowed to about $\$ 60$ billion per quarter in the first half of last year and then dropped to only $\$ 20$ billion per quarter in the second half. The decline resulted in part from a deterioration in the outlook for corporate profits and

8. Composition of U.S. capital flows, 1997-2001

Billions of dollars

\begin{tabular}{|c|c|c|c|c|c|c|c|}
\hline \multirow{2}{*}{ Item } & \multirow{2}{*}{1997} & \multirow{2}{*}{1998} & \multirow{2}{*}{1999} & \multirow{2}{*}{2000} & \multicolumn{3}{|c|}{2001} \\
\hline & & & & & Year & H1 & $\mathrm{H} 2$ \\
\hline Current account balance .. & -140 & -217 & -324 & -445 & -417 & -220 & -197 \\
\hline Capital account balance & $\mathbf{0}$ & 1 & -3 & $\mathbf{1}$ & 1 & $\mathbf{0}$ & $\mathbf{0}$ \\
\hline Financial account balance & 272 & 145 & 377 & 443 & 456 & 258 & 198 \\
\hline 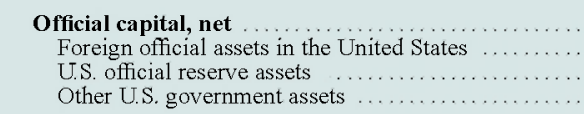 & $\begin{array}{r}18 \\
19 \\
-1 \\
0\end{array}$ & $\begin{array}{r}-27 \\
-20 \\
-7 \\
0\end{array}$ & $\begin{array}{r}\mathbf{5 5} \\
44 \\
9 \\
3\end{array}$ & $\begin{array}{r}36 \\
38 \\
0 \\
-1\end{array}$ & $\begin{array}{r}1 \\
6 \\
-5 \\
-1\end{array}$ & $\begin{array}{r}-\mathbf{1 8} \\
-16 \\
-1 \\
-1\end{array}$ & $\begin{array}{r}19 \\
22 \\
-4 \\
0\end{array}$ \\
\hline 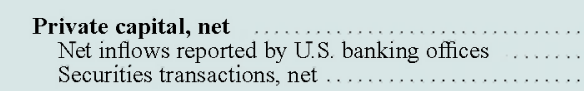 & $\begin{array}{r}254 \\
8 \\
225\end{array}$ & $\begin{array}{r}172 \\
4 \\
131\end{array}$ & $\begin{array}{r}322 \\
-22 \\
192\end{array}$ & $\begin{array}{r}\mathbf{4 0 7} \\
-51 \\
308\end{array}$ & $\begin{array}{r}\mathbf{4 5 5} \\
-9 \\
417\end{array}$ & $\begin{array}{r}276 \\
-59 \\
199\end{array}$ & $\begin{array}{r}179 \\
50 \\
218\end{array}$ \\
\hline $\begin{array}{l}\text { Private foreign net purchases }(+) \text { of U.S. securities } \\
\text { Treasury securities } \ldots \ldots \ldots \ldots \ldots \ldots \ldots \ldots \ldots \\
\text { Corporate and other bonds } \ldots \ldots \ldots \ldots \ldots \ldots \ldots \ldots \ldots \ldots \ldots \ldots \\
\text { Corporate stocks } \ldots \ldots \ldots \ldots \ldots \ldots \ldots \ldots \ldots \ldots\end{array}$ & $\begin{array}{r}344 \\
146 \\
128 \\
70\end{array}$ & $\begin{array}{r}267 \\
49 \\
172 \\
46\end{array}$ & $\begin{array}{l}323 \\
-20 \\
231 \\
113\end{array}$ & $\begin{array}{l}433 \\
-53 \\
293 \\
193\end{array}$ & $\begin{array}{r}514 \\
16 \\
371 \\
127\end{array}$ & $\begin{array}{r}281 \\
-8 \\
208 \\
82\end{array}$ & $\begin{array}{r}233 \\
24 \\
164 \\
46\end{array}$ \\
\hline 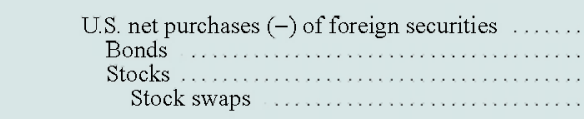 & $\begin{array}{r}-119 \\
-61 \\
-58 \\
-3\end{array}$ & $\begin{array}{r}-136 \\
-35 \\
-101 \\
-96\end{array}$ & $\begin{array}{r}-131 \\
-17 \\
-114 \\
-123\end{array}$ & $\begin{array}{r}-125 \\
-25 \\
-100 \\
-80\end{array}$ & $\begin{array}{r}-98 \\
13 \\
-110 \\
-43\end{array}$ & $\begin{array}{r}-83 \\
0 \\
-82 \\
-37\end{array}$ & $\begin{array}{r}-15 \\
13 \\
-28 \\
-6\end{array}$ \\
\hline 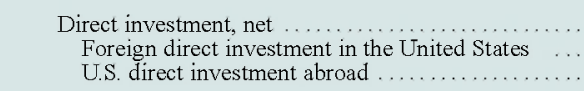 & $\begin{array}{r}1 \\
106 \\
-105\end{array}$ & $\begin{array}{r}36 \\
178 \\
-143\end{array}$ & $\begin{array}{r}146 \\
301 \\
-155\end{array}$ & $\begin{array}{r}135 \\
288 \\
-152\end{array}$ & $\begin{array}{r}2 \\
158 \\
-156\end{array}$ & $\begin{array}{r}36 \\
118 \\
-82\end{array}$ & $\begin{array}{r}-34 \\
40 \\
-74\end{array}$ \\
\hline Foreign holdings of U.S. currency & 25 & 17 & 22 & 1 & 24 & 5 & 19 \\
\hline Other & -5 & -15 & -17 & 13 & 22 & 95 & -73 \\
\hline Statistical discrepancy & -132 & 72 & -49 & $\mathbf{1}$ & -39 & -39 & -1 \\
\hline
\end{tabular}

SOURCE. BEA, U.S. international transactions accounts. 
from a significant reduction in general merger and acquisition activity. By contrast, despite the downturn in direct investment receipts, U.S. direct investment abroad actually increased modestly in 2001, to $\$ 156$ billion. Merger activity remained robust, and retained earnings by foreign affiliates of U.S. firms held up.

Capital inflows from foreign official sources were slight in 2001 , totaling only $\$ 6$ billion. To put the amount in perspective, inflows in 2000 were $\$ 38$ billion, roughly what would arise if foreign officials reinvested their interest earnings on dollar positions. For most countries, changes in official positions in the United States were modest. Some of the larger changes were in Latin America, where a sizable reduction in Argentina's holdings was offset by increases by Mexico and Brazil.

Capital account transactions, which consist mainly of debt forgiveness and wealth transfers associated with immigration, netted to $\$ 1$ billion last year, the same amount as in 2000 .

\section{PROSPECTS FOR 2002}

The projection of a consensus of forecasters is for economic activity to grow faster in the United States than in the major U.S. industrial trading partners in 2002. If this consensus forecast is borne out, then the U.S. external deficit will widen, as U.S. imports of goods and services are likely to expand more rapidly than U.S. exports of goods and services. The degree to which the deficit widens will depend largely on the strength of the economic recovery in our principal trading partners, on the lagged effects of the past appreciation of the weighted average value of the dollar on U.S. price competitiveness, and on the effects of the world economic recovery on relative rates of return on assets, including interest rates. 